УДК 330.8

ББК 65.02

DOI $\underline{10.17150 / 2308-2588.2017 .18(1) \cdot 30-52}$

Е. Е. Николаева

Ивановский государственный университет, г. Иваново, Российская Федерация

\title{
КОНЦЕПЦИИ РАСПРЕДЕЛИТЕЛЬНЫХ ОТНОШЕНИЙ В ИСТОРИИ ЭКОНОМИЧЕСКОЙ МЫСЛИ
}

\begin{abstract}
Аннотация. В статье в обобщенном виде представлена трактовка распределительных отношений представителями различных экономических направлений и школ, выделены основные категории, подходы, используемые ими. При этом в отличие от широко распространенных в учебной литературе классификаций взглядов на распределение в историко-хронологическом аспекте представлены концепции распределения на основе методологических принципов исследования.
\end{abstract}

Киючеъые слова. Воспроизводство, распределение, экономические законы, концепции, экономические школы.

E. E. Nikolaeva

Ivanovo State University, Ivanovo, Russian Federation

\section{THE CONCEPTS OF DISTRIBUTIVE RELATIONS IN THE HISTORY OF ECONOMIC THOUGHT}

\begin{abstract}
The article summarizes the treatment of distributive relations by representatives of various economic spheres and schools, identifies the main categories, approaches used by them. At the same time, in contrast to the widely distributed classifications of views on distribution in the historical and chronological aspect, the concepts of distribution are presented on the basis of the methodological principles of research.
\end{abstract}

Keywords. Reproduction, distribution, economic laws, concepts, economic school. 
Отношения распределения возникли еще в первобытном обществе по поводу добычи и дележа продукта. За время длительной эволюции человеческого общества распределительные отношения (РО) существенно изменились под влиянием политических, экономических и социальных факторов. Это нашло отражение в трактовке распределения авторами различных школ и направлений в экономической науке. Не вдаваясь в подробную характеристику взглядов представителей экономических течений, выделим наиболее существенные позиции в связи с РО, сформировавшиеся к настоящему времени, и представим их в табличной форме (табл.).

Как видно из таблицы, отношения распределения в той или иной степени находились в поле зрения всех основных экономических направлений в истории экономической мысли, начиная с XVIII века, в тесной связи с вопросами социально-экономического развития той страны, в которой формировались взгляды авторов, с конкретной эпохой. Можно выделить ряд концепций распределения.

1. Концепция кругооборота. Кругооборотные схемы связаны с условиями реализации продукта (модели кругооборота общественного продукта и капитала - Ф. Кенэ, модели кругооборота благ и доходов в экономикс, принцип круговой и кумулятивной причинности в трудах представителей неортодоксальной политической экономии Г. Мюрдаля, Н. Калдора). Указанная концепция дает понимание непрерывности производства в схеме кругооборота капитала как движения (при расширенном воспроизводстве спиралевидного движения).

Основоположник физиократии Франсуа Кенэ впервые ввел и использовал понятие «воспроизводство» как постоянное повторение производства и сбыта. Главной проблемой, которую он решал в «Экономической таблице», являлось выявление основных 2017. T. 18, № 1. C. 30-52 


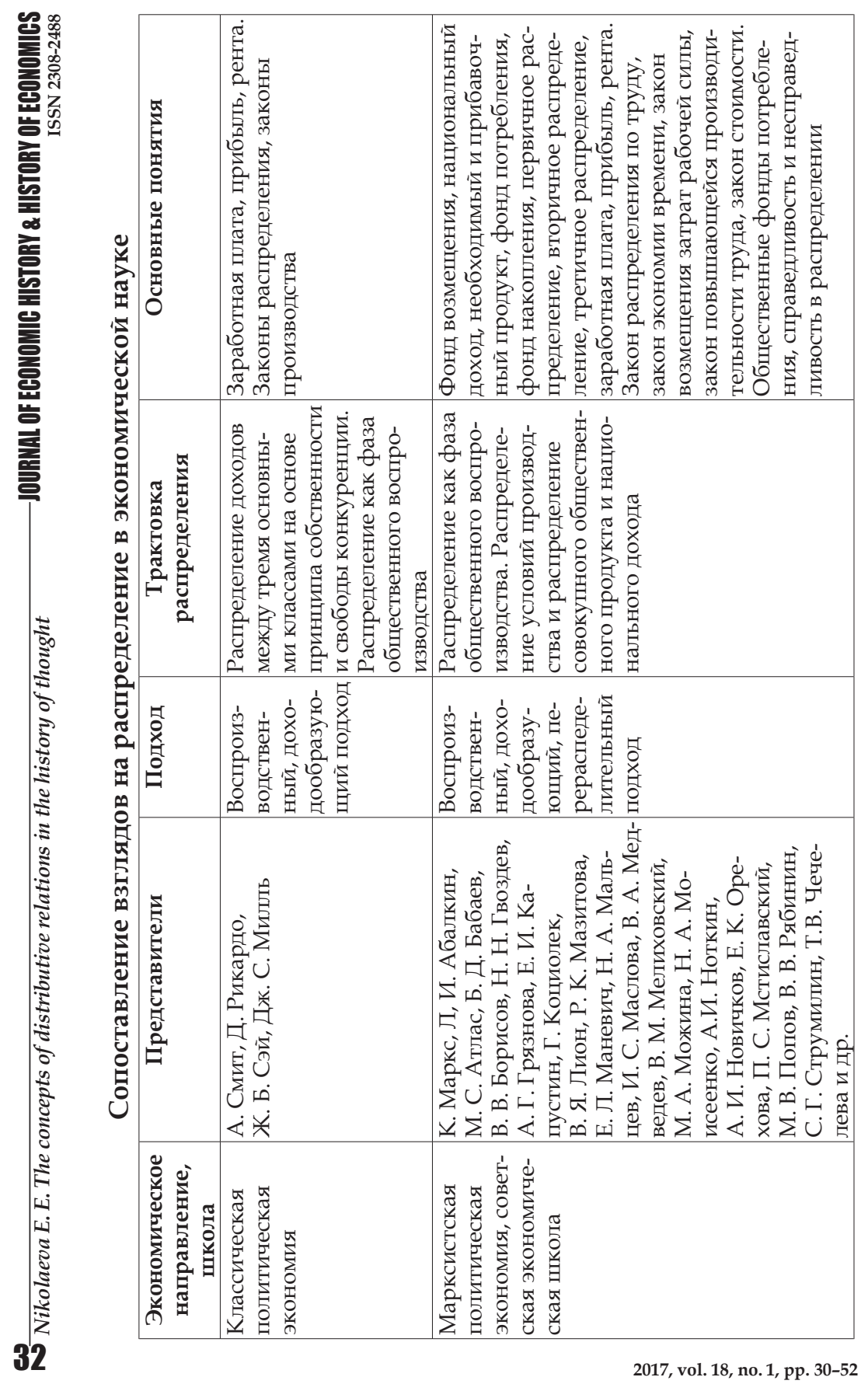




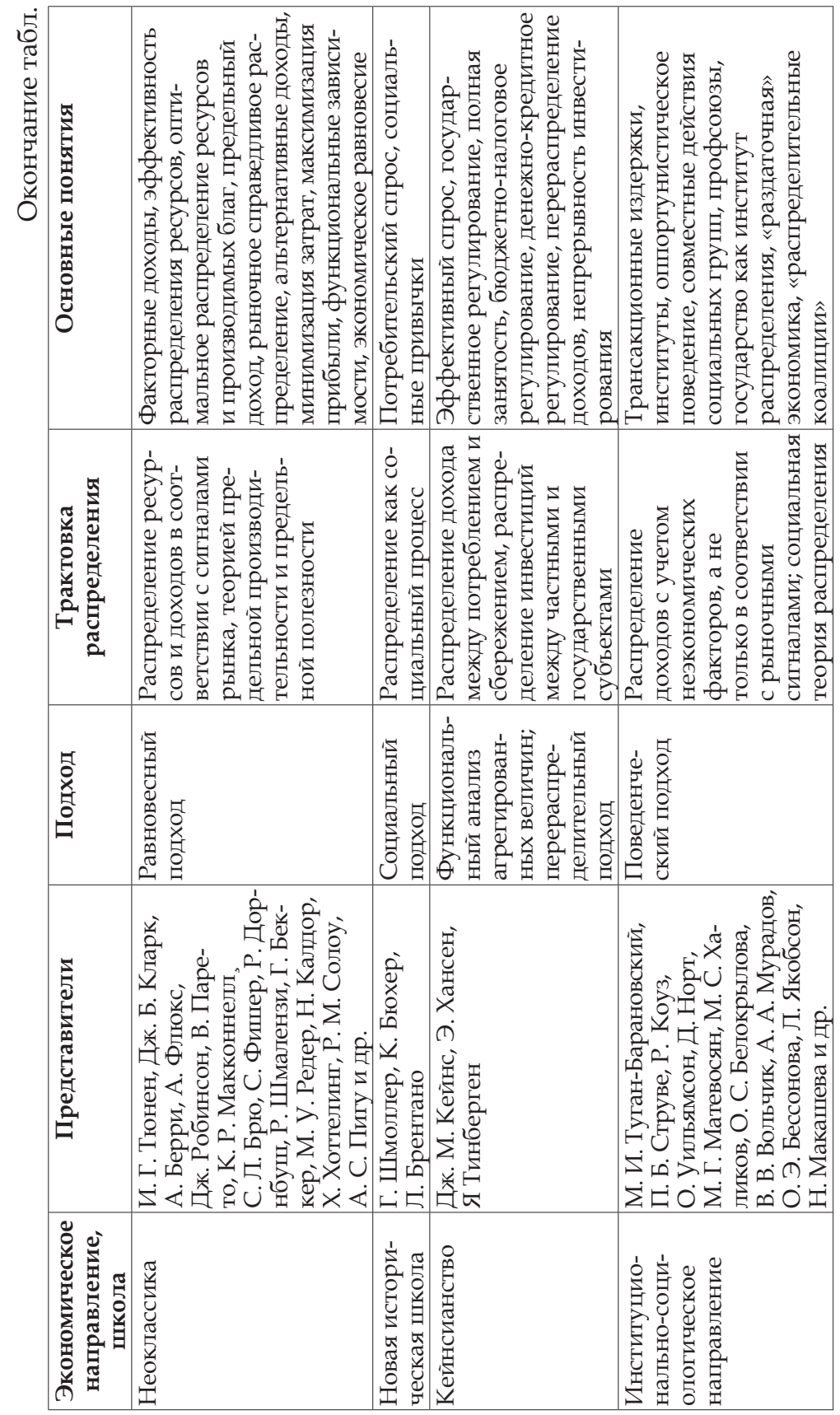

范 
народнохозяйственных пропорций, обеспечивающих развитие экономики страны. Кенэ представил схему кругооборота продукта и дохода, показывающую, как происходит реализация готового продукта общества и как формируются предпосылки простого воспроизводства. По сути, он говорил о роли распределения в функционировании экономики.

Кругооборотные схемы развивались в советский период в связи с выделением экономико-математического аспекта общественного воспроизводства и обеспечения его сбалансированности (Г. А. Фельдман, С. Г. Струмилин, В. С. Немчинов, В. С. Дадаян [6; 17; 21; 22]). Активно исследовались вопросы о сбалансированном, пропорциональном развитии общественного воспроизводства на основе схем кругооборота общественного капитала К. Маркса, деления общественного продукта и, соответственно, общественного производства на два подразделения - производство средств производства и производство предметов потребления.

2. Теория общественного воспроизводства, предполагающая рассмотрение распределения как стадии общественного воспроизводства, взаимодействующей с производством, обменом и потреблением; исследование пропорций, законов и закономерностей в условиях простого и расширенного воспроизводства (У. Петти, А. Смит, Д. Рикардо, Дж. С. Милль, К. Маркс, Ф. Энгельс, В. И. Ленин, Л. И. Абалкин, Е. С. Варга, Я. А. Кронрод, А. И. Ноткин, Д. Е. Сорокин, С. Г. Струмилин, А. И. Трахтенберг, М. С. Атлас, Б. Д. Бабаев, В. В. Борисов, Д. В. Валовой, Р. Винтрова, Н. Н. Гвоздев, С. Ю. Глазьев, А. Г. Грязнова, Е. И. Капустин, В. М. Козырев, Г. Коциолек, И. К. Ларионов, В. Я. Лион, И. И. Лукинов, В. Ф. Майер, Н. А. Мальцев, Е. Л. Маневич, И. С. Маслова, В. А. Медведев, В. М. Мелиховский, Н. А. Моисеенко, А. В. Новичков, Н. Н. Пилипенко, И. А. Погосов, М. В. Попов, М. Л. Портянко, П. Н. Федосеев, Т. В. Чечелева, С. С. Шаталин, В. Н. Щербаков 
и др.). Значение данной концепции в том, что она делает акцент, с одной стороны, на вопросе реализации продукта, а с другой, на создании условий для нового производства. В ней представлены стадии воспроизводства, а также их функциональная роль в виде фондообразования, определено место распределения в системе общественного воспроизводства.

Родоначальник английской политэкономии Уильям Петти понимал, что богатство создается в сфере материального производства, а сфера обращения обеспечивает его распределение. Купцы «не доставляют никакого продукта, а играют роль вен и артерий, распределяющих туда и назад кровь и питательные соки государственного тела, в именно продукцию сельского хозяйства и промышленности» (цит. по: [5, с. 431]).

Адам Смит с позиции трудовой теории стоимости приходит к выводу, что в процессе распределения рабочему достается лишь некоторая часть созданного его трудом стоимость товара в виде заработной платы, в основе которой лежит стоимость средств существования, необходимых для воспроизводства рабочей силы. Он разрабатывает схемы воспроизводства. Если в схеме простого воспроизводства осуществляется движение от общественного запаса к валовому продукту (доходу) и фонду возмещения, то в схему расширенного воспроизводства добавляются еще фонды сбережения и накопления. Смит рассматривает распределение чистого дохода общества.

Давид Рикардо, учитывая особую значимость РО в структуре экономических отношений общества, определял политэкономию как науку о законах распределения. Изучая распределение доходов, Д. Рикардо обнаруживает противоречия между классами, которые проявляются в обратно пропорциональной зависимости прибыли и зарплаты, прибыли и земельной ренты.

К. Маркс, определяя место распределения в системе производственных отношений общества, отмечал: 2017. T. 18, № 1. C. 30-52 
«Производство создает предметы, соответствующие потребностям; распределение распределяет их согласно общественным законам; обмен снова распределяет уже распределенное согласно отдельным потребностям; наконец, в потреблении продукт выпадает из этого общественного движения, становится непосредственно предметом и слугой отдельной потребности и удовлетворяет ее в процессе потребления. ...В процессе производства члены общества приспосабливают (создают, преобразуют) продукты природы к человеческим потребностям; распределение устанавливает пропорцию, в которой каждый индивидуум принимает участие в произведенном... Распределение определяет отношение (количество), в котором продукты достаются индивидуумам» [14, с. 714-715; 15, с. 25].

Каждый способ производства обусловливает и свои собственные формы распределения. «Отношения распределения и способы распределения выступают... как оборотная сторона факторов производства. Индивид, принимающий участие в производстве в форме наемного труда, участвует в продуктах, в результатах производства, в форме заработной платы. Структура распределения полностью определяется структурой производства. Распределение само есть продукт производства - не только по содержанию, ибо распределяться могут только результаты производства, но и по форме; ибо определенный способ участия в производстве определяет особую форму распределения, форму, в которой принимают участие в распределении» [14, с. $721 ; 15$, с. 31-32].

Указывая, что распределение на поверхности явлений выступает как распределение продуктов, К. Маркс отмечает, что «прежде чем распределение есть распределение продуктов, оно есть: 1) распределение орудий производства и 2) - что представляет собой дальнейшее определение того же отношения - распределение членов общества по различным родам производства 
(подчинение индивидов определенным производственным отношениям). Распределение продуктов есть, очевидно, лишь результат этого распределения, которое заключено в самом процессе производства и которое определяет структуру производства» [15, с. 33].

В советской школе политической экономии проблемы воспроизводства были одной из ведущих тем в экономической литературе советского периода. Распределение рассматривалось как одна из фаз (стадий) общественного воспроизводства, связующее звено между производством и потреблением. В процессе распределения выявляется доля (пропорция) агентов производства в создании и использовании совокупного общественного продукта. Этому предшествует распределение средсmb производства по отраслям народного хозяйства и предприятиям, а также распределение членов общества по различным родам производства. Ведущую, определяющую роль в единстве составных элементов процесса воспроизводства играет производство [24, с. 455]. Отношения распределения, т. е. формы движения общественных производственных отношений в фазе распределения, есть не что иное, как отношения между агентами производства, его участниками по поводу присвоения результатов производства - общественного продукта [11, с. 447].

3. Концепции распределения с позиций трудовой теории стоимости, закона распределения по труду, согласно которым распределение большей части необходимого продукта осуществляется в соответствии с количеством и качеством труда, затраченного работниками в общественном производстве (А. Смит, Д. Рикардо, Ж.-Б. Сэй, Ф. Лассаль, Дж. С. Милль, К. Маркс, Ф. Энгельс, В. И. Ленин, Л. И. Абалкин, Б. Д. Бабаев, А. Б. Берендеева, Г. И. Гуляев, Е. И. Капустин, Н. А. Квашнина, В. Я. Лион, Н. А. Мальцев, В. Ф. Майер, Р. К. Мазитова, Е. Л. Маневич, В. А. Медведев, В. В. Солдатов и др.). 
В. И. Ленин в качестве одного из важнейших принципов распределения при социализме считал принцип «за равное количество труда равное количество продукта» [12, с. 94] На первой фазе коммунистического способа производства распределение предметов потребления и услуг осуществляется по количеству и качеству труда каждого работника. Это обусловлено тем, что труд при социализме еще не стал в полной мере первой жизненной потребностью человека и нуждается в материальном стимулировании. Уровень производительности общественного труда и объём производства пока ещё не в состоянии обеспечить изобилие материальных благ и услуг. Необходим контроль со стороны общества над мерой труда и мерой потребления каждого члена общества. Этот контроль и стимулирование труда осуществляются на основе закона распределения по труду [23, с. 56].

C 60-х гг. XX в. в рамках теории распределения в советской экономической литературе развиваются вопросы стимулирования труда. Был достигнут заметный прогресс в изучении взаимосвязи требований закона распределения по труду и закона неуклонного роста производительности труда. В период начала 70-х - конца 80-х гг. XX в. происходит углубление понимания самого закона распределения по труду. Благодаря выступлениям ряда экономистов, особенно Л. И. Абалкина и Е. И. Капустина, закон все чаще рассматривается как закон распределения по результатам труда (а не по затратам, как это традиционно было принято). Такое понимание объективно способствует сближению его требований с требованиями закона стоимости и нацеливает исследователей на проблему взаимодействия этих законов уже под новым углом зрения [1, с. 171-172; 7, с. 67; 8, с. 5-7]. Вопросы формирования мотивации труда работников на основе совершенствования РО, использования закона распределения по труду развиваются и в 80-е - 90-е гг. XX в. 
Данная концепция выдвигает на первый план труд и возвышает его роль в создании стоимости товара и распределении доходов. Значение данной концепции в современных условиях снизилось.

4. Теория трех факторов производства, согласно которой каждый фактор производства (труд, капитал, земля) участвует в создании стоимости общественного продукта и получает соответствующий доход в форме заработной платы, прибыли и ренты (Ж.-Б. Сэй, Ф. Бастиа, А. Маршалл и др.). Эта концепция в литературе активно противопоставляется теории трудовой стоимости и является одной из фундаментальных положений неоклассики.

В соответствии с теорией факторов производства, когда каждый фактор получает вознаграждение в соответствии с его предельной производительностью, весь продукт полностью распределен. Именно законы распределения предопределяют персональное распределение собственности посредством распределения доходов тремя основными классами общества. А. Маршалл отмечал, что «национальный доход представляет собой совокупный чистый продукт всех факторов производства внутри страны и единственный источник оплаты этих факторов. Он подразделяется на доходы от труда, процент на капитал и, наконец, избыток для производителя, или ренту от земли, или дифференциальных преимуществ для производства» [16, с. 239].

5. Концепция распределения с позиций теории предельной производительности, получившая развитие на основе теории факторов производства и предполагающая, что вознаграждение каждого фактора производства соответствует его предельной производительности (А. Маршалл, Дж. Б. Кларк, А. Пигу, П. Х. Дуглас, А. Берри, А. У. Флюкс, К. Р. Макконнелл, С. Л. Брю и др.). В рамках неоклассической теории в трудах указанных авторов в связи с распределением речь идет о наиболее эффективном распределении 2017. T. 18, № 1. C. 30-52 
ресурсов и доходов на основе предельного продукта, предельной производительности факторов производства, предельной полезности. За рамками концепции остаются проблемы социальных отношений.

В соответствии с этим закон распределения Джона Бейтса Кларка выглядит следующим образом: капитал приносит процент, капитальные блага - ренту, предпринимательская деятельность - предпринимательскую прибыль, труд - заработную плату. Поэтому обмен, движущей силой которого является конкуренция, всегда является справедливым и эквивалентным. В своей работе «Распределение богатства» он пишет: «Свободная конкуренщия стремится дать труду то, что создается трудом, капиталистам - то, что создается капиталом, а предпринимателям - то, что создается функцией координирования. Полное изучение распределения является с этой точки зрения изучением специфического производства. Этот анализ процесса создания богатства и вменение каждому из трех факторов, совместно производящих богатство, той доли, которую каждый из них в отдельности вносит в общий продукт. Каждому фактору - определенная доля в продукте и каждому - соответствующее вознаграждение - вот естественный закон распределения» [10, с. 24]. Дж. Б. Кларк считал, что «определение величины заработной платы, процента и прибыли в соответствии с пониманием равного участия факторов производства в общественном производстве предполагает, что различные классы людей, сочетающие свои силы в производстве, не могут иметь претензии друг к другу» [Там же, с. 28].

Рассмотренные идеи неоклассической школы находят отражение в западной учебной литературе. В «экономикс» категория «распределение» используется в связи с ресурсами и неравенством населения по доходам. Так, в предисловии к русскому изданию К. Р. Макконнелл и С. Л. Брю пишут, что «конкурентная ценовая система (рыночная система) может слу- 
жить высокоэффективным механизмом обеспечения рационального распределения ресурсов... Однако не существует экономической системы без слабостей и недостатков... Ценовая система не распространяется на общественные, или социальные, блага; оценка последних входит в компетенцию правительства. Более того, ограничения конкуренции и существование издержек и выгод, не учитываемых рынком, снижают эффективность системы распределения ресурсов. В свою очередь, распределение доходов, диктуемое ценовой системой, может вступить в противоречие с принятыми в обществе принципами справедливости...» [13, с. 15-16]. В гл. 5 «Рыночная система и пять фундаментальных вопросов», в которой рассматривается функционирование рыночной системы, они отмечают, что «рыночной системе как механизму распределения общественного продукта не свойственны какие-либо этические принципы. Те домохозяйства, которым удается накопить большое количество материальных ресурсов по наследству, в результате тяжелого труда и бережливости, путем использования особой деловой сметки или посредством обмана, получают крупные доходы и, таким образом, распоряжаются большими долями общественного продукта. Другие, поставляющие на рынок неквалифицированные и сравнительно непроизводительные трудовые ресурсы в обмен на низкую заработную плату, получают скудные денежные доходы и соответственно маленькие доли национального продукта» [Там же, с. 85]. При этом отмечается необходимая деятельность государства по перераспределению дохода и ресурсов [Там же, с. 96].

Следует отметить, что советские экономисты (В. В. Новожилов, В. С. Немчинов, Л. В. Канторович) не пренебрегали в своих исследованиях предельными величинами. При решении широкого круга задач (оптимизация решений, ценообразование по замыкающим предприятиям) ее необходимо и полезно использовать. 
6. Теории оптимального распределения благ в обществе (А. Маршалл, А. Пигу, В. Парето, Г. Беккер, Н. Калдор, М. У. Редер, Р. М. Солоу, Х. Хоттелинг и др.). Наряду с теорией предельной производительности факторов производства, связанной с определением доли каждого фактора производства в созданном продукте, в неоклассике рассматриваются и другие теории, связанные с эффективным распределением ресурсов (теория распределения времени между различными видами деятельности домохозяйств Г. Беккера, теории наценки М. У. Редера, теория неиссякаемого запаса Н. Калдора). Г. С. Беккер, автор теории человеческого капитала, рассматривает распределение времени (как особого ресурса) между работой и другими видами деятельности (нерабочее время). Он отмечает, что «экономическое развитие привело к значительному сокращению рабочей недели... Распределение и эффективность нерабочего времени могут теперь оказаться чем-то более важным с точки зрения экономического благосостояния, чем рабочего, и все-таки внимание экономистов приковывается главным образом последнее» [2, с. 82). В данной теории стоимость времени рассматривается на той же основе, что и стоимость рыночных благ, исследуются изменения в соотношении рабочего и свободного времени (компромисс между потреблением и досугом), воздействие изменений в заработках, других доходах, ценах благ и в продуктивности времени, использованного на работу и потребление, влияние дохода на количество и качество потребляемых товаров. Беккер активно использует математический аппарат в исследовании].

Теория неиссякаемого запаса (Н. Калдор и др.) предполагает, что, если экономика подразделена на сектора, каждый из которых характеризуется различной предельной (и средней) склонностью к сбережению, то для установления равновесия системы требуется, чтобы распределение дохода между этими сек- 
торами порождало сумму ех ante сбережений, равных ex ante сумме осуществленных инвестиций. Данный аспект приводит к тому, что мы имеем одно уравнение с двумя неизвестными: уровнем дохода и межклассовым распределением. Доля прибыли в национальном доходе определяется долей инвестиций, которая, в свою очередь, зависит от отношения совокупного капитала к общему объему выпуска и от совокупного тепа роста (являющегося независимой переменной). Причина такой связи между прибылью и инвестициями состоит в том, что доля сберегаемой прибыли (предпринимателей, а не рантье) гораздо выше, чем доля сберегаемой заработной платы [19].

В рамках неоклассики поиском оптимального распределения благ в обществе занимался и Артур Сесил Пигу, который считал исходным в экономической теории принцип социальной справедливости, рассматривал благосостояние общества с точки зрения влияния экономической, социальной и фискальной политики государства на национальный доход и его распределение в долгосрочном и краткосрочном периоде. Пигу отмечает, что общественное благосостояние тем выше, чем более равномерно оно распределено и чем более устойчив его рост, чем меныше общего недовольства издержками его производства. Более равномерное распределение дохода между членами общества, по мнению А. Пигу, будет способствовать росту благосостояния и развитию производства. Он обосновывал идею перераспределения средств, перехода богатства «от богатых к бедным». А. Пигу разработал систему оптимального налогообложения - по принципу «наименьшей совокупной жертвы» [20].

Идеи оптимального распределения благ в условиях социализма были связаны с понятием «общественно необходимые стандарты», обеспечиваемые государством, а потребности сверх них - за счет собственных средств (С. С. Шаталин, Д. С. Львов, В. Л. Макаров и др.). 
Здесь заслуживают внимания, с одной стороны, идеи сбалансированности и экономической эффективности в распределении ресурсов, а с другой стороны - идеи социальной эффективности, роста благосостояния общества (оптимум Парето).

7. Концепция распределительно-перераспределительных отношений, предполагающая рассмотрение первичного распределения совокупного общественного продукта непосредственно в сфере материального производства, где складываются основные пропорции в распределении общественного продукта и национального дохода и формируются первичные доходы и вторичного распределения, протекающего в сфере обмена, возникающего в связи с перераспределением прибыли предприятий и доходов населения и формированием доходов учреждений и работников непроизводственной сферы (А. Смит, Дж. С. Милль, К. Маркс, В. И. Ленин, М. С. Атлас, А. Г. Грязнова, Е. И. Капустин, В. М. Козырев, В. И. Котелкин, Е. Л. Маневич, В. А. Медведев, М. Г. Муталимов, В. Я. Лион, В. В. Рябинин, Т. В. Чечелева).

В отечественной литературе советского периода выделяются четыре основные формы распределения совокупного общественного продукта.

Первая форма распределения - первичное распределение совокупного общественного продукта непосредственно в сфере производства. В рамках первичного распределения выделяются два ряда категорий, различающихся по уровню абстрактности. Один ряд фонд возмещения и национальный доход, в последний включаются необходимый и прибавочный продукт (распределение вновь созданной стоимости на необходимую и прибавочную части призвано обеспечить реализацию собственником средств производства его главной прогрессивной функции - накопления или расширения производства). Второй ряд - фонд возмещения, трансформируемый в фонды оборот- 
ных средств и амортизации (необходимый продукт выступает в виде фонда зарплаты работников материального производства) и, по советской терминологии, в фонды общественного потребления (прибавочный продукт принимает форму прибыли и ренты, к ним условно можно отнести косвенные налоги).

Вторая форма распределительных отношений собственно распределительные отношения, возникающие после распределения совокупного общественного продукта и национального дохода непосредственно в производстве. Это отношения, возникающие в связи с распределением необходимого продукта между работниками сферы материального производства (распределительные отношения в узком смысле слова)

Третья форма распределительных отношений возникает за пределами непосредственного производства и составляет сферу вторичного распределения. Вторичные распределительные отношения уже протекают в сфере обмена, они весьма специфичны, формируются особые законы распределения. Практически это отношения, которые возникают в связи с перераспределением прибыли предприятий и доходов населения. Этими отношениями определяются доходы учреждений и работников непроизводственной сферы.

Четвертая форма распределительных отношений образуется между обменом и потреблением - третичные распределительные отношения. Здесь осуществляется обмен денежных доходов населения на предметы потребления и оказанные платные услуги. Изменение цен на товары и услуги, товарный дефицит, степень доступности дефицитных товаров различным социальным группам, инфляционные процессы способны значительно изменить результаты первичного распределения национального дохода страны и внести существенные изменения в доходы, потребление и условия воспроизводства рабочей силы.

2017. T. 18, № 1. C. 30-52 
Эта концепция развивалась в условиях баланса народного хозяйства, а при переходе к системе национального счетоводства ее значение необоснованно упало. Однако материальное производство по-прежнему играет достаточно важную роль в экономике.

8. Социальные теории распределения, предполагающие при распределении национального дохода взаимодействие многочисленных социальных групп (П. Б. Струве, М. И. Туган-Барановский, Г. Шмоллер, К. Бюхер, Т. Веблен, Й. Шумпетер и др.). Одними из первых важность изучения социальных аспектов механизма формирования спроса на рынке показали представители новой исторической школы: Густав Шмоллер, Карл Бюхер, Луйо Брентано. Рынок в их теории предстает не как универсальный механизм распределения ресурсов, а как социальный институт, функционирование которого отражает особенности экономической системы в целом. Российская экономическая мысль конца XIX - начала XX в. представлена историко-этическим, психологическим и социальным направлением. Представители легального марксизма - течения в отечественной экономической мысли 90-х гг. XIX в. - Петр Бернгардович Струве и Михаил Иванович Туган-Барановский сформулировали теорию «социального распределения». В ней распределение представляет собой социальный феномен, предполагающий совместное действие многочисленных социальных групп. Поэтому оно изображалось им в виде борьбы различных социальных групп за «дележ» общественного пирога. Размер доли, приходящийся тому или другому классу, определяется количеством произведенных благ и «социальной силой» данного общественного класса. Важнейшая распределительная категория - заработная плата, величина которой регулируется производительностью труда и социальной силой рабочего класса.

Социальная теория распределения в своих основных чертах служит отправным пунктом анализа у 
многих современных исследователей, занимающихся вопросами заработной платы, прибыли, ренты и других форм доходов. Новшество, которое внесли современные экономисты, состоит в трактовке взаимоотношений между рабочими и капиталистами как своеобразной двусторонней монополии, как социального партнерства. В современных социальных концепциях широко рассматриваются вопросы, связанные с дифференциацией населения по доходам и имуществу (М. А. Можина, Л. С. Ржаницына, Н. М. Римашевская, А. Шевяков и др.).

9. Концепции распределения, предполагающие участие государства в перераспределении национального дохода в обществе посредством фискальной, экономической, социальной политики (Дж. М. Кейнс, А. Пигу, Э. Хансен, Я. Тинберген, Б. Жювенель, С. С. Шаталин, Д. С. Львов, С. Ю. Глазьев, Н. П. Федоренко, Г. Г. Фетисов, В. Дасковский и др.).

Не рассматривая как таковую фазу распределения в общественном воспроизводстве, Джон Мейнард Кейнс исследовал распределение дохода между потреблением и сбережением; распределение инвестиций между субъектами по принципу «частные» и «государственные», разрабатывал программу государственного регулирования экономики, направленную на ограничение автономии частного предпринимательства и регулирования рыночного процесса с целью стабилизации экономики. Она включала систему антициклического регулирования для стимулирования эффективного спроса и обеспечения полной занятости, которые рассчитаны на краткосрочный период действия в условиях недогрузки производственных мощностей и массовой безработицы [9].

Вопросы справедливого распределения доходов, перераспределения доходов при посредстве государства с опорой на опыт социалистических стран находят отражение в ряде работ западных ученых. Так, в 2017. T. 18, № 1. C. 30-52 
1952 г. вышла книга Бертрана де Жювенеля «Этика перераспределения», в которой рассматривается перераспределительная деятельность государства и её влияние на экономическое развитие [18].

В рамках этой концепции возникает две проблемы: финансирование экономики с использованием средств бюджета на основе а) инфляционного подхода (Э. Хансен) и б) долгового подхода (формирования госдолга). Кроме того, в условиях современной России особое развитие в связи с распределением получил аспект межбюджетных отношений, трансфертных платежей, а также целевых федеральных программ.

10. Институциональные теории распределения, связанные с действием институтов, механизмов и экономическим поведением субъектов (идеи «общества всеобщего благосостояния»). Само экономическое развитие рассматривается как следование этим нормам, преодоление препятствий, противоречий в этом развитии (Т. Веблен, Р. Коуз, О. Уильямсон, Д. Норт, Дж. К. Гэлбрейт, О. С. Белокрылова, О. Э. Бессонова, В. В. Вольчик, М. М. Кораблев, Н. А. Макашева, А. А. Мурадов, М. С. Халиков, Л. И. Якобсон и др.).

Если неоклассика выдвигала исключительно идеи рыночной практики - распределение в соответствии с сигналами рынка, то у институционалистов проблема выбора и распределения - это не только учет рыночных (ценовых) сигналов, но и неэкономических факторов. В связи с учетом неэкономических факторов к институционалистам можно отнести и К. Маркса в связи с понятием надстройки и ее диалектическим использованием, а также Дж. С. Милля, который рассматривает социально-экономические проблемы общества на основе разграничения законов производства и законов распределения.

В рамках институционализма, популярного в современной экономической теории России, развивается теория институциональных трансформаций, ко- 
торая оперирует категорией «раздаток» как синоним категории «распределение». О. Э. Бессоновой рассматривается экономика «либерального раздатка», отличающаяся такими чертами, как служебный контракт вместо административно-директивных распоряжений; госзаказ вместо госплана (распределение средств на конкурсной основе вместо предписанного отраслевого распределения ресурсов (фондирование); госкорпорация с вертикально-интегрированной структурой и самостоятельностью ее звеньев вместо отраслевых комплексов с иерархическим подчинением структур; бюджетный хозрасчет вместо закрепленности затрат за статьями расходов, оплата труда при этом будет связана с результативностью через введение доплат к бюджетной тарифной ставке и социального пакета, дополняющего зарплату; государственно-частное партнерство, обеспечивающее набор разнообразных механизмов сосуществования государственных и частных форм вместо идеологического обоснования возможности использования рыночных механизмов в раздаточной экономике [4].

В современной экономической и социологической литературе в связи с вопросами распределения в институциональном аспекте рассматривается эффективность распределения ресурсов и доходов под влиянием групп с особыми интересами («распределительных коалиций»). По мнению исследователей, группы с особыми интересами замедляют экономический рост, снижая скорость перераспределения ресурсов между сферами деятельности или отраслями в ответ на появление новых технологий или условий. Одним из очевидных способов, которыми они добиваются этого, лоббирование помощи выхода из затруднительного положения фирм, потерпевших фиаско, что приводит к отсрочкам и затрудняет перемещение ресурсов в те сферы деятельности, где они имели бы большую продуктивность [3; 25]. 
11. Либеральная концепция саморегулирующегося рынка, согласно которой стихийно, на основе действия рыночных сигналов, прежде всего цены, решаются вопросы: что производить? как производить? для кого производить? (представители Манчестерской школы, современные неоклассики - монетаристы, сторонники теории предложения, школа рациональных ожиданий). Доходы участников складываются в соответствии с теорией факторной производительности, а в качестве принципа распределения выступает рыночной критерий - экономическая эффективность.

Изучение распределительных отношений как одного из актуальных направлений современной экономической теории невозможно без изучения существующих концепций. Их знание способно помочь адекватно решать многие социально-экономические проблемы в экономике России.

\section{Өписок использованной литературы}

1. Абалкин Л. И. Диалектика социалистической экономики / Л. И. Абалкин. - М., 1981. - 351 с.

2. Беккер Г. С. Теория распределения времени / Г. С. Беккер // Вехи экономической мысли : рынки факторов производства. Т. 3 / под ред. В. М. Гальперина. - СПб. : Экономическая школа, 1999. - С. 82-121.

3. Белокрылова О. С. Институциональные особенности распределения доходов в переходной экономике / О. С. Белокрылова, В. В. Вольчик, А. А. Мурадов. - Ростов н/Д. : Изд-во Рост. ун-та, 2000. - 110 с.

4. Бессонова О. Э. Вектор институционального развития России: от квазирынка к либеральному раздатку / О. Э. Бессонова // Экономическая социология. - 2008. - Т. 9, № 2. C. 15-28. - Режим доступа : https:/ / ecsoc.hse.ru/2008-9-2.html.

5. Всемирная история экономической мысли. [В 6 т.] / гл. редкол. : В. Н. Черковец (гл. ред.) и др. - М. : Мысль, 1987. Т. $1 .-606$ c.

6. Дадаян В. С. Экономико-математическое моделирование социалистического воспроизводства/ В. С. Дадаян. - М. : Экономиздат, 1963. - 343 с. 
7. Капустин Е. И. Некоторые социально-экономические проблемы труда в 80-х годах / Е. И. Капустин / / Социалистический труд. - 1981. - № 4. - С. 64-75.

8. Капустин Е. И. Активное использование заработной платы для интенсификации общественного производства и роста его эффективности / Е. И. Капустин / / Социалистический труд. - 1983. - № 4. - С. 3-16.

9. Кейнс Дж. М. Общая теория занятости, процента и денег : пер. с англ. / Дж. М. Кейнс. - М. : Прогресс, 1978. - 494 с.

10. Кларк Дж. Б. Распределение богатства : пер. с англ. / Дж. Б. Кларк. - М.: Экономика, 1992. - 447 с.

11. Кронрод Я. А. Законы политической экономии социализма. Очерки методологии и теории / Я. А. Кронрод. - М. : Мысль, 1966. - 581 с.

12. Ленин В. И. Государство и революция / В. И. Ленин / / Полн. собр. соч. 5-е изд. М. : Политиздат, 1969. - Т. 33. C. 3-120.

13. Макконнелл К. Р. Экономикс : принципы, проблемы, политика : в 2 т. : пер. с англ. / К. Р. Макконнелл, С. Л. Брю. М. : Республика, 1992. - Т. 1. - 399 с.

14. Маркс К. Введение (Из экономических рукописей 1857-1858 годов) / К. Маркс // Маркс К., Энгельс Ф. Соч. 2-е изд. - М. : Госполитиздат, 1958. - Т. 12. - С. 709-738.

15. Маркс К. Экономические рукописи 1857-1859 годов (первоначальный вариант «Капитала»). Часть первая // Маркс К., Энгельс Ф. Соч. - 2-е изд. - М. : Политиздат, 1968. - T. 46. - Ч. 1. - 560 с.

16. Маршалл А. Принципы экономической науки : пер. с англ. / А. Маршалл. - М. : Изд. группа «Прогресс», 1993. T. 1. - 416 с. - (Экономическая мысль Запада).

17. Немчинов В. С. Избранные произведения / В. С. Немчинов : в 6 т. Т. 5 : Планирование и народно-хозяйственные балансы. - М. : Наука, 1968. - 430 с.

18. Никифорова О. М. Реферат книги Бертрана де Жювенеля «Этика перераспределения» / О. М. Никифорова // Экономические науки. - 1991. - № 1. - С. 118-122; № 2. С. 131-139.

19. Николас Калдор (1908-1986) [Электронный ресурс] // Галерея экономистов. - Режим доступа : http://gallery. economicus.ru/cgi-bin/frame_rightn.pl?type=in\&links=./in/ kaldor/biogr/kaldor_k1.txt\&name=kaldor\&img=brief.gif

20. Пигу А. Экономическая теория благосостояния : пер. с англ. / А. Пигу. - М. : Прогресс, 1985. - Т. 1. - 512 с. 
21. Струмилин С. Г. Очерки социалистической экономики СССР (1929-1959) / С. Г. Струмилин. - М. : Госполитиздат, 1959. - 419 c.

22. Фельдман Г. А. К теории темпов народного дохода / Г. А. Фельдман // Плановое хозяйство. - 1928. - № 11. С. 146-170; № 12. - С. 51-178.

23. Экономическая энциклопедия. Политическая экономия / гл. ред. А. М. Румянцев. Т. 1. - М.: Советская энциклопедия, 1972. - 560 с.

24. Экономическая энциклопедия. Политическая экономия / Гл. ред. А. М. Румянцев. Т. 3. - М.: Советская Энциклопедия, 1979. - 624 с.

25. Якобсон Л. Распределительные коалиции в постсоциалистической России / Л. Якобсон, Н. Макашева // Общественные науки и современность. - 1996. - № 1. - С. 5-14.

\section{Информация об авторе}

НиколаеВа Елена ЕВгенъевна - доктор экономических наук, доцент, заведующая кафедрой экономической теории, Ивановский государственный университет, 153025, г. Иваново, ул. Ермака, 39, e-mail: politeconom@yandex.ru.

\section{Author}

Elena E. Nikolaeva - D.Sc. in Economic, Associate Professor, Head of the Economic Theory Department, Ivanovo State University, 39, Ermak str., Ivanovo, Russian Federation, 153025, e-mail: politeconom@yandex.ru.

\section{Библиографическое описание статьи}

Николаева Е. Е. Концепции распределительных отношений в истории экономической мысли / Е. Е. Николаева / / Историко-экономические исследования. - 2017. - Т. 18, № 1. - C. 30-52. - DOI: 10.17150/2308-2588.2017.18(1).30-52.

\section{Reference to article}

Nikolaeva E. E. The concepts of distributive relations in the history of economic thought. Istoriko-ekonomicheskie issledovaniya $=$ Journal of Economic History \& History of Economics, 2017, vol. 18, no. 1, pp. 30-52. DOI: 10.17150/23082588.2017.18(1).30-52. (In Russian). 